\title{
EDUCATION OF SOCIAL VALUES BY THE USE OF PARTIAL EDUCATIONAL PROGRAMS FOR KINDERGARTEN
}

\author{
Kharkivska A. A., Dmytrenko K. A.
}

\section{INTRODUCTION}

Currently, the development of education in Ukraine is characterized by systemic transformations in the educational field. In particular, the new Law of Ukraine "On Education" (2017) was adopted, the Conceptual foundations for reforming secondary school of the New Ukrainian School were introduced, with an emphasis on building a system of human values. Even though the Concept of the New Ukrainian School includes general secondary education reforming, the values stated in this document, in the context of implementing the principle of continuity between the links of preschool and primary education, should be shared by teachers at preschool education, students and their parents ${ }^{1}$.

The implementation of the basic principles of the New Ukrainian School makes it necessary to reconsider approaches to educating children in the face of modern educational challenges, to focus the educational process on building the system of ideals that are significant at the current stage of the society. It is about social values that are basic to human behavior and should be the formation of the personality.

That is why the development of social values is important for both children and future educators. However, there are issues to accomplish the task:

- in the adopted normative-legal acts regulating education, including preschool, there are no clearly stated guidelines, recommendations on social values development;

- the lack of adequate educational and methodological materials that would allow the teacher to practice social values development;

- insufficiently clarified methodology of developing individual social values, starting from preschoolers, which motivates to define the appropriate principles, methods and techniques.

The aforementioned issues also apply to developing social values of future preschool teachers.

\footnotetext{
${ }^{1}$ Нова українська школа : порадник для вчителя / за ред. Н. Бібіка. Київ : ТОВ «Видавничий дім «Плеяди»», 2017. 206 с. URL: https://nus.org.ua/wpcontent/uploads/2017/11/NUSH-poradnyk-dlya-vchytelya.pdf (дата звернення:
} 29.08.2019). 
It is impossible to solve the issues without studying the state-of-the-art software, isolating the substantive components of existing educational programs to meet the purpose of preschool education.

Therefore, there is a need in analyzing current preschool education programs in line with current requirements and justifying the feasibility of their use at preschool educational establishments in order to develop social values.

So, as a conclusion, we note that the variety of program support in practice implements the idea of progressive development of domestic preschool on the principles of democracy and pluralism, the right to choose all participants in the educational process: teachers, parents, children - and also stimulates the further development of various scientific schools in Ukraine, which have the potential for the development and experimental testing of modern programs and methodological support for them. Building the educational process in preschool institutions according to several programs allows you to more fully take into account the interests, desires, needs, opportunities and makings of each child for the timely holistic development of the child's personality.

It is worth noting that value orientations are an important characteristic of a child's mental development. They reflect the level of subjective activity of the baby, the degree of growing up and harmonization of all his psychological achievements, which are externally manifested in behavior, relationships with other people, in cognitive, subject - practical and game activities. That is why ensuring proper psychological and pedagogical support for the process of forming a child's value orientations in preschool institutions and in the family is one of the most important tasks of education.

\section{Analysis of previous researches and publications of problems education of social values by the use of partial educational programs for kindergarten}

The issues of developing values and valuable orientations are analyzed in the works of R. Thornberg, E. Oğuz, I. Solomons, I. Fataar, M. Berkowitz, M. Chowdhury, J. Patil, D. Tombare, R. Harade, M. Mahmood, S. Mashlah, A. Parrilla, A. Zhumadullaeva, S. Konyrbaeva, B. Duanbaevac, A. Alhooli, Z. Al-Shammari, O. Beh, O. Pometun and others.

In the works of the aforementioned scholars, the issues of building personality on the path to spiritual values, education of dignity culture, value attitude to the society and the state, forming national and cultural identity are explored. The issue of using modern educational technologies in the process of value formation of student youth is investigated. 
In the work of R. Thornberg and E. Oğuz ${ }^{2}$ presents the results of the study of the value education issue at schools in Sweden and Turkey. For us, the views of Swedish and Turkish educators on the core values of high priority are valuable. They are respect for other people, kindness, empathy, tolerance, justice. At the same time, educators attach great importance in developing the values to democratic process of education. The results of the study are relevant for our country as well, because in the national education, preference is given to the above-mentioned values and the subject-subjective interaction between the student and the tutor.

M. Berkowitz $z^{3}$ in his work focuses on developing values when studying at school. The researcher thoroughly reveals the value of value-oriented education in schools of different levels.

The Conceptual Study of the Value Education Issue in the Context of Learning in South Africa by I. Solomons, I. Fataar is particularly noteworthy, which emphasizes the use of holistic approach to value education and dialogue meetings of representatives from different countries to solve the above issue.

M. Chowdhury substantiates the importance of morality, values in the context of globalization and rapid advances in science and technology. The researcher in detail reveals the need to introduce morality, values, ethics and education in science education.

In the work of M. Mahmood the important role of values for the high school teacher is emphasized. In particular, it is stressed that students are more disciplined if the teachers treat them with love and respect. This confirms the idea, which we fully share, that values must first be formed in the teachers themselves so that they can later develop them in youth.

The opinion of S. Mashlah regarding the role of personal values for those who work, since most students both work and study.

A. Parilla believes that by cultivating values it is possible to build the culture of behavior among students. The researcher argues that behavioral and relationship issues are addressed indirectly rather than included in school curriculum or planning. However, school is increasingly considered as a place where in addition to academic training, people learn to live with others, build relationships, be respectful, express tolerance and be good, and therefore there is a need to consider the value aspect when planning and designing programs.

2 Медіасвіт для дошкільнят : парціальна програма для дітей старшого дошкільного віку / за ред. О. Волошенюк, Г. Дегтярьової, В. Іванова. Київ : Академія української преси ; Центр вільної преси, 2018. 96 с.

3 Програма «Нова українська школа» у поступі до цінностей. Київ, 2018. 40 с. URL: https://ipv.org.ua/prohrama-nova-ukrainska-shkola (дата звернення: 30.08.2019). 
A. Zhumadullaeva, S. Konyrbaeva, B. Duanbaevac and others provide a thorough analysis of the crisis of values as a social issue. To solve it, scientists offer to introduce value-oriented curricula and disciplines.

In our opinion, the results of the study concerning the issue of developing moral values in preschoolers in Kuwait, carried out by A. Alhooli, Z. AlShammari are worthy. The conclusion of the researchers on the need to introduce special programs aimed at developing values is vital.

Let's consider the studies on the issue in Ukrainian science.

In particular, I. Beh et al. designed the program "The New Ukrainian School" in the approach to values, which defines clear priorities in educating children with formed competencies that will help them live in the future as a decent, high-moral, professionally successful, healthy and happy person.

In our opinion, the works by O. Pometun and others are valuable in practically implementing modern ideas of education, including social values in the framework of implementing the international project "Education for Sustainable Development in Action". In particular, the main objectives of the above project are to acquire the skills of environmental, economic and social behavior for both children and parents, teachers ${ }^{4}$.

The issue of training preschoolers in the conditions of developing information and communication technologies are revealed in the work of I. Timofeeva 5 . The author thoroughly recommended to preschool teachers to implement the educational process in the optional component of the Basic component of preschool education "Computer literacy".

However, there are not enough works to cover the practical aspects of developing values in preschoolers by using current educational programs, including partial ones.

The aim of the study is to analyze partial programs for preschoolers when developing social values.

\section{Main material of problems education of social values by the use of partial educational programs for kindergarten}

Today, in the face of constant changes for preschool teachers, they face different tasks aimed at developing a valuable attitude both to themselves and to others. Social values are of particular importance because they reflect the qualities that a preschooler must have before school. In the future, having social values is the main feature of the personality of today.

${ }^{4}$ Про розроблення програм для дошкільної освіти : інструктивно-методичний лист від 28 лютого 2013 р. № 1/9-152. URL: http://old.mon.gov.ua/img/zstored/files/ 1_9-152.doc (дата звернення: 29.08.2019).

5 Тимофєєва I. Я у світі комп'ютерної грамоти : методичні поради. Маріуполь : TOB «ППНС», 2017. 136 c. URL: http://timofeeva.in.ua/images/docs/bibliograf/ Comp_gram.pdf (дата звернення: 05.09.2019). 
To address the challenges currently faced by preschool teachers, there have been introduced partial educational programs aimed at developing the preschooler's personality in accordance with current requirements. Their use in the educational process promotes the development of social values among preschoolers, including responsibility, initiative, creativity, etc.

Partial programs are intended for the in-depth study of one or more components, close in content, of separate directions along specific educational lines. The purpose of these programs is to broaden the content of the invariant (or variant) component of the existing complex programs, to carry out the tasks of the Basic Component of Preschool Education (BCPE), both its invariant and variant component.

BCPE is the State standard of pre-school education in Ukraine and regulates the following:

- regulatory requirements for the level of training a child of 6 (7) years old (education, development and manners);

- competencies acquired by the child for further education at school.

It deals with the issue of using programs to organize the activity of preschool educational establishments and groups in separate priority areas (artistic, and aesthetic, physical and health-strengthening, cognitive, ethnocultural, communicative and speaking, etc.), group work, including in general secondary school and extracurricular classes. as well as for in-depth individual work in pre-school educational establishments with children who have abilities, interests, inclinations to learn the content of individual semantic educational lines, tend to master certain types of activities.

The basis for developing these programs is the Basic Component of Preschool Education, which is created on the basis of children age-based competency approach and structured along such educational lines as "Personality of the Child", "Child in the Society", "Child in the Environment", "Child in the world of culture", "Child's Play", "A child in the sensory-cognitive space", and "The Speech of a child" and optional educational lines "Computer literacy", "Foreign language", "Choreography", "Chess"6.

Let us analyze some partial educational programs.

One of the partial programs that can be used to promote the development of social values in pre-school establishments is the "Aflatot" program of social and financial literacy for preschool children ${ }^{7}$. Its value lies in the

${ }^{6}$ Базовий компонент дошкільної освіти / А. Богуш та ін. Київ, 2012. 26 с. URL: https://mon.gov.ua/storage/app/media/doshkilna/bazovij-komponent-doshkilnoyiosviti-na-sajt-ostatochnij.pdf (дата звернення: 06.09.2019).

7 Програма соціальної та фінансової освіти «Афлатот». URL: $\quad$ https://mon.gov.ua/ua/osvita/doshkilna-osvita/profesijna-skarbnichka/osvitnijproekt-aflatot (дата звернення: 28.08.2019). 
orientation of the content of the program to a positive personal identity, developing such child's qualities as the love for the dearest people, contributes to formation a friendly relationship with others. It meets the needs of society, a social group, personality and the requirements for the implementation of educational tasks.

Another one that has high educational potential is the program "Unlimited World of LEGO Play". Its realization allows forming in the child beliefs that concerning the estimation of events significance, phenomena and certain determinant principles that make up definite types of social values.

The social learning program for effective interaction of children from 4 to 6-7 Years "Learning to Live Together" was chosen as an example of a program that provides not only the formation of social skills in preschool children, but also the formation of beliefs that are significant for society.

We cannot overlook programs aimed at building computer competence: "Computer literacy for kids"10, "Media education for preschoolers"11, "Fairy tales and colors" $"$. In addition to the formation of an information-literate personality the tasks of these programs include the development of values necessary for the person of modern society.

Let's analyze each of the above programs in more detail.

Partial program of social and financial literacy of preschool children «Aflatot» is aimed at children from 3 to 6 years and is implemented in 112 countries of the world within the framework of the project of social and financial education. The project implements the ideas of the worldwide movement in social and financial education for children aged 3 to 18 through the implementation of the "Aflatot", "Aflatun" and "Aflatin" programs. The education of children comes with the involvement of a fairy-tale character, the star Aflatun, who flew from space to children on the Earth.

8 Програма розвитку дитини від 2 до 6 років та методичні рекомендації "LEGO" / О. Рома та ін. Київ : The LEGO Foundation, 2016. 140 c. URL: file:///C:/Users/User/Downloads/\%D0\%9B\%D0\%95\%D0\%93\%D0\%9E\%20(8).pdf.

${ }^{9}$ Піроженко Т., Хартман О. Парціальна програма з розвитку соціальних навичок ефективної взаємодії дітей від 4 до 6-7 років «Вчимося жити разом». Київ : Алатон, 2016. $32 \mathrm{c}$.

10 Семизорова В., Вайнер О., Болотова О. Парціальна програма для дітей старшого дошкільного віку «Комп'ютерна грамота для малят». Тернопіль : Мандрівець, 201. 32 с.

${ }^{11}$ Освіта для сталого розвитку в дії. Міжнародний освітній проект для шкільної молоді та дорослих. URL: http://esd.org.ua/node/476 (дата звернення: 30.08.2019).

${ }^{12}$ Казки і фарби: парціальна програма розвитку творчих здібностей дітей 4-6 років на заняттях із малювання 3 використанням елементів медіаосвіти / за ред. О. Волошенюк, Г. Дегтярьової, В. Іванова. Київ : Академія української преси ; Центр вільної преси, 2018. 204 с. 
The purpose of the "Aflatot" program is to develop socio-emotional space of children; forming of bases of social values, full-fledged development of personality of preschoolers.

The program is aimed at educating social values, gaining knowledge of finances, budgets, resources, savings, planning, children's rights; formation of confidence in children. It consists of five elements that are identified as key in the program.

1. Personal Understanding and Research. This element allows the preschool teacher to best stimulate the child's self-discovery process by exploring his / her true self. In the process of education children become more self-confident, they have new positive attitudes towards their personality, and adequate self-esteem is formed. At the same time, such social values as initiative, activity, critical thinking, self-control are developed.

2. Rights and Obligations. The content of this element incorporates the principles of the United Nations Convention on the Rights of the Child, provides for joint actions with adults that allow children to become aware of their rights and develops responsibility, tolerance, dignity, justice, respect for others and honesty.

3. Savings and Expenses. In the process of implementation of this component a responsible attitude is formed for children to consume and to economically use different types of resources (for example, natural, financial, etc.). Children are educated in reasoning and further developed critical thinking.

4. Planning and budget. The meaningful filling of this component of the program involves, through planning and budgeting, to facilitate the child's understanding of his or her own ability to influence his or her future, to set personal goals, to adequately assess the environment and to be aware of its needs. The key to the implementation of this element is the education of selfcontrol, the development of social and emotional intelligence.

5. Children's social and financial initiative. This element is a summary and foresees the further development of the qualities that were formed during the previous stages of education and upbringing. As a result of mastering this component of the program, the child begins to perceive himself as part of society and becomes an active participant. At the same time, initiative, activity, perseverance, ability to cooperate with others acquire further development.

Therefore, the implementation of this program in the educational process will promote the development of a wide range of social values.

The next partial program, which, in our opinion, is noteworthy, is the program for the development of a child from 2 to 6 years, "Unlimited World of LEGO Play", which since 2015 is used in pre-school establishments. 
The purpose of the program is to educate a person with strong convictions, to unlock, preserve and develop each child's inner potential; formation of holistic outlook; enriching the game experience; developing a creative approach to creating structures and gaining knowledge in the modern flow of information; promoting successful self-fulfillment in adulthood.

We have highlighted this program because it promotes the formation of social skills and design abilities; provides comprehensive development of the child's personality as an active participant in social life; involves learning through the game. The child awakens curiosity to the outside world, develops critical thinking, increases cognitive activity.

The material base is the constructor toy "LEGO", which is represented by two types "DUPLO" and "SYSTEM". "DUPLO" is a volume by size for children, both young and old. In "SYSTEM" the details are half that of "DUPLO". This type of constructor toy is best used in middle and older age groups. The peculiarity of the LEGO structure is that parts of both types are interconnected. The use of a constructor toy allows developing creativity, perseverance, instills a love of learning.

Children develop technical skills, the ability to concentrate attention, to cooperate in a team, a sense of self-confidence; develop fine motor skills, thinking, memory, imagination, creativity, creativity, fantasy. The program helps to realize the ideas of preschoolers, the ability to build and fantasize and see the outcome of their work.

Therefore, the result of the program is the development of socially significant qualities in children, which will help them to realize themselves in later life.

Another partial program for the development of social skills for effective interaction of children from 4 to 6-7 years "Learning to live together" (by T. Pirozhenko and O. Hartman) is focused on the needs of modern society.

The purpose of the program is to facilitate the adaptation of temporarily displaced preschoolers and their parents in host communities around the conflict zone and the development of life, communication skills, active citizenship, and value for the individual in society.

The implementation of this program is aimed at solving the problem of developing in preschoolers the ability to cooperate in a team, interact with others, to realize their aspirations and to realize them in society among peers and adults.

It is important that the program takes into account the specifics of working with children of preschool age, realizes the tasks of such educational lines of the Basic component of preschool education, as "Personality of the child" and "Child in society", and promotes intellectual and socio-moral development. 
The program provides for the use of various forms of education including games and artistic activities of preschool children. Great attention is also paid to interacting with the immediate surroundings of the child, who are family members and peers.

Such approach promotes the communicative interaction of the child with the surrounding world, allows educating the preschoolers such qualities as tolerance, respecting for others, the ability to forgive.

The program defines the child as the highest social value, is based on recognition of the rights of the child, respect for his personality, takes into account his individual characteristics. Based on the principle of humanization of interpersonal relationships, the program promotes the development of social abilities, emotional and social intelligence, the formation of active civic position of all participants in the educational process.

The work of a preschool teacher under this program will help to develop the necessary life skills in children, as well as to educate preschoolers such social values as confidence, dignity, justice, respect, equality, tolerance, compassion, charity. Preschoolers learn how to solve problems, prevent conflicts through negotiation and reconciliation.

According to the program, the focus is on the child, who has a complex inner world that make up his ideas about himself, thoughts and feelings.

A special feature of the program is to enable preschool teachers, practical psychologists and preschoolers' parents to develop skills for effective interaction and communication with children. In particular, the program provides information on the phased work on improving your child's communication skills. Emphasis is placed on the need to communicate without aggression, preventing conflict situations and avoiding punishment. This, in turn, educates a harmoniously developed personality with formed social values, teaches responsibility for his actions.

Reference points the educational aims of the program are vital characteristics of competence, especially social and communicative.

The program has four substantive areas, the tasks of which are to provide systematic educational activities on effective interaction of children with peers and adults, focus on the prevention of aggression behavior.

The result of the implementation of the program is vital to the competent child, who is not only informed person, but also aware, mobile, able to operate in different conditions creatively, to make appropriate decisions, knowing how to adapt to them and change them. Children learn to recognize their own mistakes, but develop dignity, the ability to achieve goals, relying on their natural abilities.

In order to achieve the result, it is important to rely on the emotional world of the child, to enrich his emotional experience, to respect his feelings, 
to stimulate a conscious understanding of the causes and effects of actions, to control himself and to withstand negative phenomena.

Thus, the implementation of the program allows developing values related to communication, relationship with other people, the ability to live in society and interact with their environment.

At the present stage of society, the formation and development of computer literacy is of particular importance. For this reason, the Computer Literacy educational line is highlighted separately in the Elementary component of pre-school education in the variant component of pre-school education content. Educational activity along this educational line involves acquaintance with the computer and its components, mastering basic special concepts, basic skills when working with the computer.

In view of this, a partial program was created to ensure the development of older preschool children through the above educational line: "Computer literacy for children" (authors: O. Bolotova, O. Wainer, V. Semizorova).

The purpose of the program is social education through the means of information technology, as well as the education of older preschool children with computer literacy and the development of information skills. Its implementation contributes to the development of cognitive processes in preschoolers, belief in their own capabilities and provides comprehensive personality development:

- acquaintance with the computer, ways of using it with the keyboard, "mouse";

- forming the ability to understand and use special terminology: keyboard, screen, program, disk, key, computer games, etc.;

- teaching elementary techniques of work with the computer in the course of implementation of game and educational programs intended for children of preschool age;

- acquiring preschoolers with the ability to observe safe behavior when using a computer;

- development of logical and abstract thinking of preschoolers;

- education of information culture, perseverance, discipline and accuracy.

The program consists of three stages.

The first stage "Getting to know your computer", provides preschoolers with information about computer components, ways to work with a computer using a keyboard, a "mouse", and promotes the ability of children to understand and use special terminology, adhere to safe behavior working with a computer and educate attention, coscientiousness. 

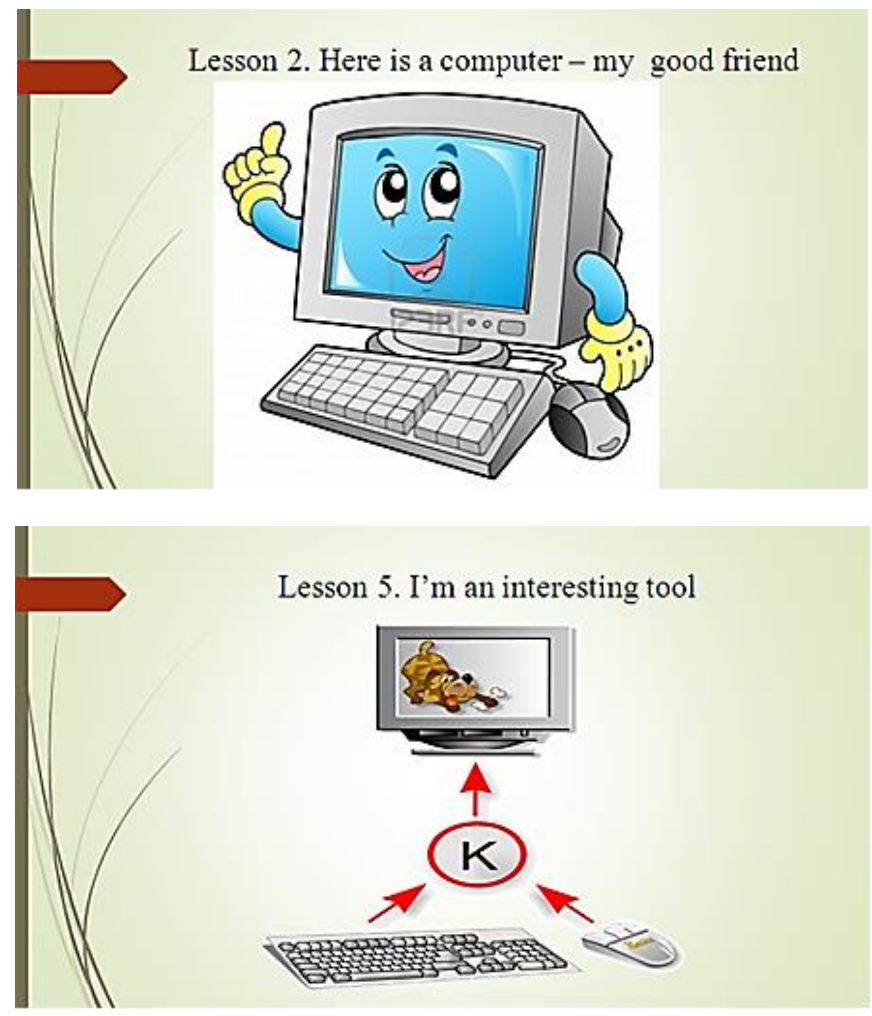

The second stage, "Computer Wizard", promotes pupils' cognitive interests by familiarizing them with the Paint Graphic Editor.

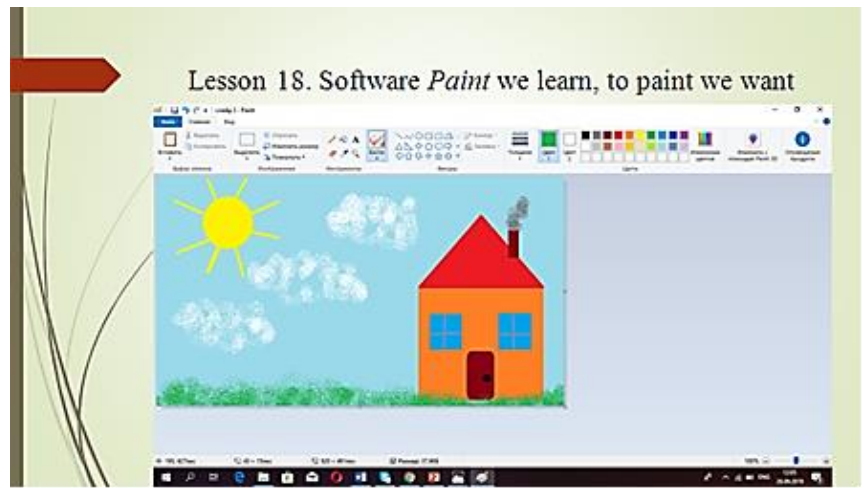


During the lessons, preschoolers learn basic computer skills playing game tasks.

The third stage, "Computer and Game", is focused for mastering preschoolers elementary methods of work with the computer performing game and educational tasks, familiarization with educational programs and formation ideas about the Internet.

Studying this topic helps children become more confident, believe in their abilities and strength.

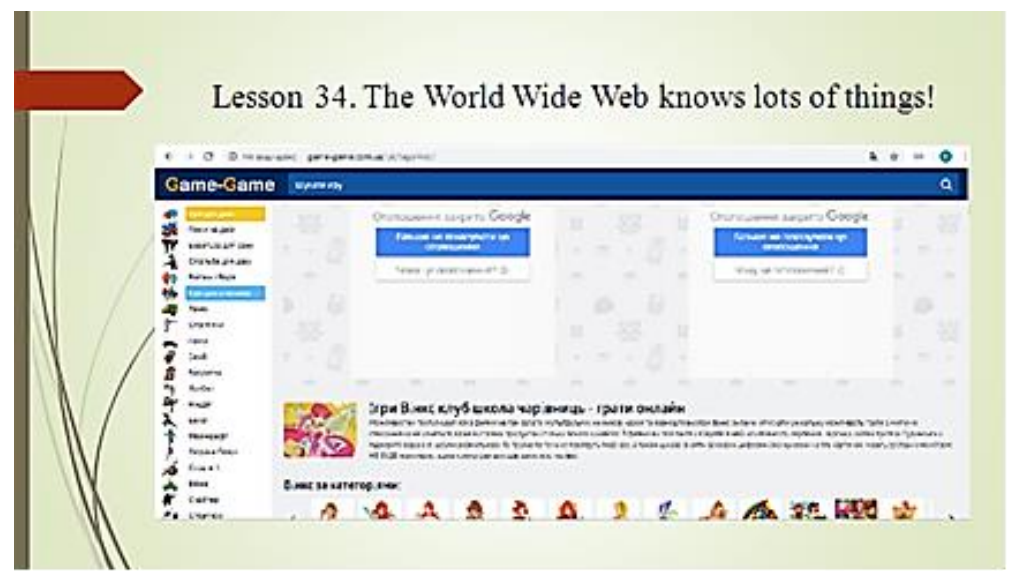

Lessons for preschoolers are held in a specially equipped room with compliance with sanitary and hygienic requirements.

During and after the lessons, a set of exercises for the prevention of visual and static fatigue is provided for the pupils.

Each lesson consists of theoretical and practical parts and provides:

- educator's story;

- conversation;

- use of didactic games;

- practical work on the computer.

Licensed Curricula for Preschoolers containing exercises and games, promote the formation of children's computer literacy skills in practice.

Other partial programs that enable the implementation of the Basic Literacy component of the Computer Literacy Educational Line are programs for older preschoolers "Media Education for Preschoolers" and "Fairy Tales and Paints".

Partial program "Media Education for Preschoolers" is aimed at older preschool children 
Its content is in accordance with the principles of innovative pedagogy and involves creative cooperation of the teacher and children, promotes the education of social values, tolerant attitude to others, the development of creative personality, the formation of the ability to use the knowledge and skills acquired in everyday life.

The work of an educator under this program involves the use of effective techniques aimed at the development of reflexive, creative and critical thinking basics, among which is TRWZ, elements of the Nikitins' educational games, Dinesh's blocks, and Keizer's sticks. It is also suggested to use the reading methods of the Nikitins, Lars-Eric Hal's and the EPA model working with information provided by Swedish elementary school teachers.

According to the program, institution of preschool education is regarded as media center for kids and adults in today's world.

The result of the implementation of the program is mastering the requirements of the Basic component by pupils.

Partial program "Fairy Tales and Paints" for children of middle and older preschool age (by T. Chashka) is aimed at developing the creative abilities and social values of children from 4 to 6 years. It is implemented over two years and involves the use of media education in drawing lessons.

The program is focused on the speech, intellectual and social development of children in the process of fine arts activity, the end result of which is the acquisition of pupils' social, artistic and productive competence, and requires the educator to use traditional and non-traditional drawing techniques and the active involvement of media such as presentations, media cartoons, music, print media and so on. The result of the pupils' education is creating their own original product.

The program provides a system of drawing lessons using elements of media education and media in the middle and senior groups of pre-school institutions, which can be used during the work in groups in the PSI.

The result of the program "Tales and Paints" is:

- social development of personality

- the development of associative-colour perception;

- forming an emotional and positive attitude to the drawing process;

- media literacy that will appear in children's abilities to decode and create information (to come up with a plot, composition), to use media for self-expression and creativity, to understand the influence of media and forms of information presentation in them.

Curriculum applications contain materials that the educator can use in drawing lessons in work with children: a list of media, reproductions of paintings, illustrations to works of art, schemes of decoding mediatext and analysis (comparison) of various types of media texts, examples of 
children's work with paintings, and also some aspects of preschoolers' analysis of media texts.

Thus, we consider the partial programs for the formation of computer literacy, which allow children not only to acquire special techniques and skills in working with the computer, but also promote the education of social values, including persistence, activity, interest, creativity, critical thinking, self-control. And the use of computer games for preschoolers educate the love of learning, the ability to appreciate beauty, love, kindness, respect for others in them.

Therefore, the use of the aforementioned partial educational programs will promote the implementation of the principles of personally-oriented learning:

- child's development and self-development taking into account his / her abilities, inclinations, interests, values and subjective experience;

- creation of conditions for realization and self-realization of personality;

- ensuring the child's subjectivity through the ability to influence the course of the activity;

- not only gaining knowledge, developing skills, but also the formation of competences specified in the Basic component of preschool education;

- education of basics of social values.

\section{CONCLUSIONS}

In the context of educational reform, in particular the implementation of the Conceptual foundations for reforming the New Ukrainian High School, the education of social values that should be shared by teachers, children and parents of children is of particular importance.

One of the ways of education of social values in preschool institutions is to use partial educational programs in the educational process, including the programs of social and financial literacy of preschool children "Aflatot", "The boundless world of playing with LEGO", to develop social skills of effective interaction of children from 4 to 6-7 years "Let's learn to live together", formation of computer literacy.

The use of partial educational programs "Aflatot", "The boundless world of playing with LEGO", "Learning to live together" in the formation of computer literacy contributes to the development of a child's personality, the formation of a system of ideals that are important to society and represent social values.

Prospects for further research: we see further prospects in the development of means for determining the level of formation of social values.

\section{SUMMARY}

The article describes the current state and relevant issues of education development in Ukraine. It deals with establishing the relationship between 
the tasks of reforming general secondary education, which are outlined in the Conceptual Framework of the New Ukrainian School, and the purpose of preschool education in the context of continuity between preschool and primary education.

The author analyzes the current state of the issue of developing values and value orientations by both foreign and domestic researchers. The importance of education of social values is revealed.

The peculiarities of partial programs and their difference from complex ones are outlined. Partial programs for developing social values at preschool education have been characterized: Aflatot, LEGO's World of Limitless Creativity, Learn to Live Together, and computer literacy programs for preschoolers (Computer Literacy for Children), Media World for Preschoolers, Fairy Tales and Paints).

The requirements of the Basic Component of Preschool Education have been updated and the ways of implementing the requirements using the above-mentioned programs are presented. According to each program, the goals, key elements, principles and implementation results are defined. The connection between the principles of personality-oriented learning and the objectives of the partial programs Aflatot, LEGO's World of Limitless Creativity, Learn to Live Together, Computer Literacy for Children, Media World for Preschoolers, Fairy Tales and Paints.

The practical aspect of using the programs is presented in the article: forms of work, class subjects, description of materials and visual aspects to have classes, etc.

\section{REFERENCES}

1. Нова українська школа : порадник для вчителя / за ред. Н. Бібіка. Київ : ТОВ «Видавничий дім «Плеяди»», 2017. 206 с. URL: https://nus.org.ua/wp-content/uploads/2017/11/NUSH-poradnyk-dlyavchytelya.pdf (дата звернення: 29.08.2019).

2. Медіасвіт для дошкільнят : парціальна програма для дітей старшого дошкільного віку / за ред. О. Волошенюк, Г. Дегтярьової, В. Іванова. Київ : Академія української преси ; Центр вільної преси, 2018. 96 с.

3. Програма «Нова українська школа» у поступі до цінностей. Київ, 2018. 40 c. URL: https://ipv.org.ua/prohrama-nova-ukrainska-shkola (дата звернення: 30.08.2019).

4. Про розроблення програм для дошкільної освіти : інструктивнометодичний лист від 28 лютого 2013 p. № 1/9-152. URL: http://old.mon.gov.ua/img/zstored/files/1_9-152.doc (дата звернення: 29.08.2019). 
5. Тимофєєва I. Я у світі комп'ютерної грамоти : методичні поради. Маріуполь : ТОВ «ППНС», 2017. 136 с. URL: http://timofeeva.in.ua/ images/docs/bibliograf/Comp_gram.pdf (дата звернення: 05.09.2019).

6. Базовий компонент дошкільної освіти / А. Богуш та ін. Київ, 2012. 26 c. URL: https://mon.gov.ua/storage/app/media/doshkilna/bazovijkomponent-doshkilnoyi-osviti-na-sajt-ostatochnij.pdf (дата звернення: 06.09.2020).

7. Програма соціальної та фінансової освіти «Афлатот». URL: https://mon.gov.ua/ua/osvita/doshkilna-osvita/profesijnaskarbnichka/osvitnij-proekt-aflatot (дата звернення: 28.08.2019).

8. Програма розвитку дитини від 2 до 6 років та методичні рекомендації "LEGO" / О. Рома та ін. Київ : The LEGO Foundation, 2016. 140 c. $\quad$ URL: file:///C:/Users/User/Downloads/\%D0\%9B\% D0\%95\%D0\%93\%D0\%9E\%20(8).pdf (дата звернення: 30.08.2019).

9. Піроженко Т., Хартман О. Парціальна програма 3 розвитку соціальних навичок ефективної взаємодії дітей від 4 до 6-7 років «Вчимося жити разом». Київ : Алатон, 2016. 32 с.

10. Семизорова В., Вайнер О., Болотова О. Парціальна програма для дітей старшого дошкільного віку «Комп'ютерна грамота для малят». Тернопіль : Мандрівець, 201. 32 с.

11. Освіта для сталого розвитку в дії. Міжнародний освітній проект для шкільної молоді та дорослих. URL: http://esd.org.ua/node/476 (дата звернення: 30.08 .2019$)$.

12. Казки і фарби : парціальна програма розвитку творчих здібностей дітей 4-6 років на заняттях із малювання 3 використанням елементів медіаосвіти / за ред. О. Волошенюк, Г. Дегтярьової, В. Іванова. Київ : Академія української преси ; Центр вільної преси, 2018. 204 с.

\section{Information about the authors:}

Kharkivska A. A.,

Doctor of Pedagogical Sciences, Professor, Vice-Rector of Research and Educational Work Municipal Establishment "Kharkiv Humanitarian-Pedagogical Academy" of the Kharkiv Regional Council 7, Rustaveli lane, Kharkiv, 61001, Ukraine

Dmytrenko K. A., $\mathrm{Ph}$. D. in Pedagogic, Associate Professor at the Department of Social Work Municipal Establishment "Kharkiv Humanitarian-Pedagogical Academy"

of the Kharkiv Regional Council 7, Rustaveli lane, Kharkiv, 61001, Ukraine 